Steinunn Pórðardóttir,

Specialist physician in internal medicine and geriatric medicine, PhD, Landspítali University Hospital, Reykjavík Iceland

doi.org/10.17992/lbl.2018.05.183

\title{
Alzheimer-sjúkdómur faraldur 21. aldarinnar
}

Alzheimer-sjúkdómur einkennist af uppsöfnun amyloid-skella og taugatrefjaflækja í heilavef, sem í kjölfarið leiðir til sívaxandi taugafrumudauða og rýrnunar heilans. Pessar sjúklegu breytingar valda yfirleitt fyrst versnun á skammtímaminni, en lifi sjúklingurinn nógu lengi nær sjúkdómurinn að hafa áhrif á öll svið vitrænnar getu og að lokum einnig á hreyfigetu. ${ }^{1}$ Pótt Alzheimer-sjúkdómur leggist mun fremur á eldri einstaklinga en pá sem yngri eru og hækkandi aldur sé sterkasti áhættupáttur sjúkdómsins, á hann ekkert skylt við eðlilega öldrun. Sá misskilingur hefur lengi staðið rannsóknum á sjúkdómnum fyrir prifum og enn pann dag í dag er margfalt hærri upphæðum veitt til rannsókna á krabbameinum, hjarta- og æðasjúkdómum og HIV/AIDS, svo eitthvað sé nefnt. Á peim sviðum læknisfræðinnar hefur undraverðum árangri verið náð á undanförnum árum og áratugum, sem skilar sér í hærri lífaldri og par með í auknum fjölda einstaklinga með heilabilun, meðal annars af völdum Alzheimer-sjúkdóms.

Heilabilun er gríðarlega algengt vandamál í eldri aldurshópum og er Alzheimer-sjúkdómur orsök 60-70\% heilabilunartilfella. Talið er að fjöldi peirra sem pjást af Alzheimer-sjúkdómi tvöfaldist á um pað bil 20 ára fresti. ${ }^{2}$ Í Bandaríkjunum eru 5,7 milljónir einstaklinga greindir með Alzheimer-sjúkdóm, sem gróflega jafngildir 5700 Íslendingum. ${ }^{3}$ Beinn kostnaður heilbrigðiskerfisins par í landi við meðferð og umönnun einstaklinga með heilabilun voru 277 milljarðar Bandaríkjadala árið 2017 og óbeinn kostnaður við umönnun á vegum aðstandenda var metinn vera 232 milljarðar Bandaríkjadala sama ár. $^{3}$ Séu pessar kostnaðartölur yfirfærðar á Ísland mundi beinn og óbeinn kostnaður við meðferð og umönnun einstaklinga með heilabilun hérlendis nema 50 milljörðum íslenskra króna árlega. Hér er pví um að ræða gríðarlegan útgjaldalið í heilbrigðismálum sem að óbreyttu á eftir að tvöfaldast á næstu 20 árum, en erfitt er að ímynda sér hvernig samfélagið á að geta staðið undir peirri aukningu.

Nú pegar gætir mikils úrræðaleysis í málaflokknum, sem veldur sjúklingum með heilabilunarsjúkdóma og aðstandendum peirra ómældum pjáningum. Í pessum skrifuðu orðum eru 200 einstaklingar á bið eftir sérhæfðri dagpjálfun á höfuðborgarsvæðinu og geta peir átt von á að purfa að bíða í allt að tvö ár. Á tveimur árum getur orðið mikil afturför í sjálfsbjargargetu einstaklings með heilabilun sem leiðir til pess að margir eru orðnir of veikir til að nýta sér úrræðið pegar að peim kemur og hafa pá eytt pessum tíma heima, oft undir sólarhringseftirliti örpreyttra aðstandenda. Biðin eftir hjúkrunarrými er einnig óhóflega löng og veldur pví að margir sjúklingar með heilabilun hrekjast á milli mismunandi deilda innan Landspítala mánuðum saman áður en peir komast loks í örugga höfn.
Vandinn liggur pví í augum uppi og mætti ætla að menn reru að pví öllum árum að bæta úr pví ófremdarástandi sem nú ríkir og búa sig undir hina miklu fjölgun einstaklinga með heilabilun sem fram undan er. Svo er pó ekki. Enn hefur engin stefna verið mótuð í málefnum einstaklinga með heilabilun hér á landi. Engar tölur eru til um raunverulegan fjölda einstaklinga með heilabilun hérlendis, hvað pá um beinan og óbeinan kostnað við meðferð og umönnun peirra. Раð hlýtur að teljast aðkallandi að kortleggja betur málaflokk sem líklega veltir um 50 milljörðum árlega og er jafn hratt vaxandi og raun ber vitni. Ekkert bólar enn á auknum úrræðum á sviði heimahjúkrunar, sérhæfðra dagpjálfana og fjölbreyttra búsetuúrræða fyrir pennan hóp.

Раð er að sjálfsögðu einkar mikilvægt að styðja við pá einstaklinga sem pegar eru komnir með Alzheimer-sjúkdóm og létta líf bæði sjúklingsins sjálfs og aðstandenda hans. Fyrirbyggjandi aðgerðir eru hins vegar ekki síður mikilvægar með pað fyrir augum að seinka upphafi fyrstu einkenna sjúkdómsins um einhver ár, sem gæti fækkað einstaklingum með heilabilun til framtíðar og par með sparað ómældar fjárhæðir. Höfundar greinar sem birtist í Lancet sumarið 2017 benda á 9 lífsstílspætti sem samanlagt liggja að baki um pað bil 30\% heilabilunartilvika. Pessir pættir eru lágt menntunarstig, hár blóðprýstingur, offita, heyrnartap, reykingar, punglyndi, félagsleg einangrun og sykursýki. ${ }^{4}$ Hér eru pví til staðar augljós sóknarfæri samfélagsins alls til að stemma stigu við yfirvofandi heilabilunarfaraldri.

Ef spár bjartsýnustu manna ganga eftir verða innan 10 ára komin lyf gegn Alzheimer-sjúkdómi sem hægja verulega á próun sjúkdómsins, eða hindra hann jafnvel alveg. Pað er hins vegar ekkert fast í hendi og við verðum pví að undirbúa okkur undir pann raunveruleika sem nú blasir við. Stefnumótun og kortlagning á málaflokknum, parfagreining, fjármagn til rannsókna og almenn og víðtæk lýðheilsuíhlutun til forvarna eru verkefni sem parf að ráðast í ekki síðar en í dag. Við purfum að taka slaginn núna. Málefnið snertir okkur öll.

\section{Heimildir}

1. Scheltens P, Blennow K, Breteler MMB, de Strooper B, Frisoni GB, Salloway S, et al. Alzheimer's disease. Lancet 2016; 388: 505-17.

2. Qiu CX, De Ronchi D, Fratiglioni L. The epidemiology of the dementias: an update. Curr Opin Psychiatr 2007; 20: 380-5.

3. Alzheimer's Association 2018 Alzheimer's Disease Facts and Figures.

4. Livingston G, Sommerlad A, Orgeta V, Costafreda SG, Huntley J, Ames D, et al. Dementia prevention, intervention, and care. Lancet 2017; 390: 2673-734. 